\title{
The Effects of Cross-Border E-Commerce on International Trade and Economic Growth: A Case of China
}

\author{
Ho Thi Hang (Suri Ho $)^{1} \&$ Togo Adjouro ${ }^{1}$ \\ ${ }^{1}$ School of Economics, Shanghai University, Shanghai, China \\ Correspondence: Ho Thi Hang (Suri Ho), School of Economics, Shanghai University, Shanghai, China. Tel: \\ 1-613-947-3592.
}

Received: August 26, 2021

Accepted: November 17, $2021 \quad$ Online Published: November 25, 2021

doi:10.5539/ijef.v13n12p82

URL: https://doi.org/10.5539/ijef.v13n12p82

\begin{abstract}
With the financial crisis in 2008 and its negative consequence on traditional foreign trade and economic growth, China has adopted cross-border e-commerce as a new international business model. The purpose was to enhance international trade and sustain economic growth. However, despite the remarkable increase of cross-border e-commerce, China's traditional international trade and economic growth have continued to grow slowly. This paper used the ARDL bounds test over the period 2005-2020 to examine the effect of China's cross-border e-commerce on international trade and economic growth. The findings from our research indicate that in both the short-run and long-run, cross-border e-commerce has positively impacted international trade and economic growth in China. Therefore, in order to promote trade and economic growth, the government should continue to support the development of cross-border e-commerce.
\end{abstract}

Keywords: China, Cross-Border e-commerce, international trade, economic growth

\section{Introduction}

With the financial crisis of 2008 and the popularization of internet technology, traditional trade has gradually slowed down, and cross-border e-commerce (CBEC) has emerged as a new business model. CBEC refers to an international business transaction conducted in different countries through e-commerce platforms. It allows consumers to get information from other countries and directly buy goods from foreign retailers or suppliers. Companies also benefit from this type of business that opens new markets and gives them access to new customers. Like some developed countries, the government of China has formulated several policies aimed to support the development of CBEC. The CBEC customs clearance process has been optimized, inspection and quarantine regulatory measures improved, and trade tax policies classified. Moreover, CBEC companies operating overseas markets have to get financial support, and since 2020, over 105 comprehensive Pilot Zones have been established.

As a consequence of these policies, China cross-border has become the world's largest CBEC market, with 291.8 million cross-border online consumers in 2020. Furthermore, the transaction volume of cross-border e-commerce in China has dramatically increased since 2008. According to China E-commerce Research Center, it was 0.8 trillion yuan in 2008 which accounted for over 4.4 percent of the total trade volume of that year. By 2013, cross-border e-commerce transactions in China reached 2.7 trillion yuan, accounting for 10.5 percent of the total trade of this year. In 2018, it rose from 8.8 trillion yuan(accounting for 29.9 percent of total import and export trade volume) to 12.5 trillion yuan in 2020 (over 39.2 percent of total trade volume). According to the structure of China's CBEC, it is mainly dominated by exports. In 2020, the country's CBEC exports accounted for 75 percent of the total cross-border transaction volume. This highlights the global market's capacity for Chinese goods and confirms the Cross-border E-commerce in driving exports (Yue, 2017). But during the same period, as cross-border e-commerce has grown, total trade and economic growth decreased. The country's trade share to GDP fell from 57.61 percent to 37.45 percent, while GDP growth dropped from 9.65 percent to 6.75 percent.

Empirically, some authors using different methodology have examined the effect of CBEC on international trade in China and found mixed results. Also, if some studies have addressed the link between e-commerce and economic growth in China, few studies have investigated the effect of CBEC on economic growth. Therefore, it is essential to fill this research gap by investigating the long-run and short-run impact of cross-border e-commerce on China's international trade and economic growth. 
The rest of this article is organized as follows: the second section briefly reviews the literature on the relationship between cross-border e-commerce and trade as well as between cross-border e-commerce and economic growth. Section 3 presents the methodology, and section 4 shows the empirical results. Finally, section 5 shows the conclusion and recommendations.

\section{Brief Literature Reviews}

\subsection{Cross-Border E-Commerce and International Trade}

Empirically, economist researchers have analyzed the link between international trade and cross-border e-commerce in China. While most have found that cross-border e-commerce positively affected the international trade, some demonstrated the opposite.

Wang et al. (2017) used least square regression to test the relationship between cross-border e-commerce and international trade in 31 provinces of China over the period 2011-2015. They found a significant positive relationship between them. More specifically, their findings indicated that increasing cross-border e-commerce (CBEC) by 1 percent would increase China's total trade volume by 0.68 percent. Employing a multiple regression model, Zhu (2017) found that during 2008-2014, any increase of cross-border e-commerce by 1 percent has increased trade facilitation by 2.9 percent. Wang and Yu (2018) empirically analyzed the relationship between cross-border e-commerce development and traditional foreign trade in China. The results from the VAR test indicated a positive relationship between them. More, they found that a 1 percent increase in cross-border e-commerce will increase trade by about 0.401 percent. Qin and Bryna (2018) employed a Person correlation coefficient analysis to investigate the effect of cross-border e-commerce on international trade(proxies by three indicators) in China from 2011 to 2016. While they found a positive and significant link between cross-border e-commerce and merchandise trade, the impact of CBEC on international trade volume and exports was insignificant. Chai and $\mathrm{He}$ (2019) empirically analyzed the interactive relationship between China's cross-border e-commerce and foreign trade between 2008 and 2018. The findings from the VAR model showed a positive link between them. Also, the authors found a bidirectional causality with them in the case of China. Using the cointegration and granger causality tests, Lu (2019) explores the link between foreign trade and cross-border e-commerce in China from 2008 to 2016. He demonstrated a long-term equilibrium relationship between them. Specifically, he found that every 1 percent increase in cross-border e-commerce will increase China's foreign trade by about 0.19 percent. Also, the Granger causality test indicated a unidirectional causality running from trade to CBEC. Zheng and Zhang (2020) analyzed the relationship between cross-border e-commerce and agricultural product export of China during the period 2008-2019. Using the entropy method, they found a positive link between them. Yuan et al. (2020) employed the VAR model and cointegration test to examine the relationship between cross-border e-commerce and foreign trade transactions in China during 2004-2008. The results indicated the long-run relationship between them. The Granger causality test shows a unidirectional causality running from foreign trade transactions to cross-border e-commerce transactions. Liu (2020) also used the VAR model and confirmed the positive link between CBEC and foreign trade. Zhang and Chen (2020) used the Granger causality test and found bidirectional causality between the two. Chang (2021) used a gravity model to explore the impact of cross-border e-commerce on exports of goods and services from 2000 to 2018. The results indicated a positive relationship between them. However, the effect of CBEC seems to be much greater on exports of services than on exports of goods. Wang et al. (2021) used the fixed effects regression to explore the effect of international e-commerce on China exports. They found a significant positive relationship between international e-commerce and China exports from 2006-2019. Specifically, every increase in foreign e-commerce by 1 percent will increase China's exports by 0.28 percent.

Contrary to them, Zhang et al. (2018) analyzed the impact of cross-border e-commerce on China's import and export trade from 2008 to 2016. The results from the OLS method indicated that import and export trade would decrease by 3.68 if cross-border e-commerce increased by 1 unit in the short term. Yao and Yan (2019), employing the OLS method, also found a negative relationship between them during the period 2008-2018. From their finding, any increase of cross-border e-commerce by 1 percent will decrease China's traditional import and export by 0.55 percent when other variables remain constant.

\subsection{Cross-Border E-Commerce and Economic Growth}

Empirically, if some studies have addressed the link between e-commerce and economic growth in China, only a few have investigated the impact of cross-border e-commerce on economic growth in China.

Liu (2013) employed the GDP accounting by expenditure method to analyze the impact of e-commerce on economic growth from 1997 to 2011 in the case of China. He found a positive relationship between them. Employing the multiple linear regression method, Qu (2014) also found a positive link between e-commerce and 
economic growth in China during the period 1997-2012. Sayed (2017) used a cointegration test and error correction model to analyze the relationship between the development of e-commerce and economic growth in China from 2000 to 2015 . He found that e-commerce development positively promotes economic growth.

Regarding the relationship between cross-border e-commerce and economic growth, all the authors (Qianyu, 2017; Liu, 2017, etc.) found it positive. Qianyu (2017) analyzed the relationship between economic growth and cross-border e-commerce transactions. The findings from the least square method showed that for every 1 trillion yuan increase in the scale of cross-border e-commerce, China's economic growth would increase by 5.29 trillion yuan. Liu et al. (2019) adopted the PVAR model to explore the link between cross-border e-commerce and GDP in 13 CBEC pilot cities in China. The results show a positive relationship between them. According to them, every increase in CBEC by 1 percent will increase GDP by approximately 0.09 percent. Ma et al. (2021) determined whether cross-border e-commerce improved regional economic growth and economic convergence in China from 2015 to 2018. They found that CBEC contributes to both regional economic growth and economic convergence. However, while there is no significant difference in the promotion effect of CBEC on the economic growth of eastern and mid-western provinces, it tends to weaken the trend of economic convergence in east China.

\section{Model, Data and Methodology}

\subsection{Model and data}

Following Wang et al. (2017), the relationship between cross-border e-commerce and trade openness will be formulated as follows:

$$
O P E N=f(G D P C, C B E C)
$$

In the econometric format, the equation 3.1 written as follows:

$$
\mathrm{OPEN}=\beta_{0}+\beta_{1} \mathrm{GDPC}+\beta_{2} \mathrm{CBEC}+\varepsilon_{t}
$$

-Where t indicate time trend; $\beta_{0}$ : constant; $\beta_{1}, \beta_{2}$ are coefficients; $\varepsilon_{t}$ : error term

-OPEN: Openness to international trade( proxy by the sum of exports and imports as a share of GDP)

-GDPC: GDP per capita

-CBEC: Cross-border E-commerce growth

By adding the logarithm to both sides of equation 2, equation 3 will be written as follows:

$$
\text { LnOPEN }=\beta_{0}+\beta_{1} \text { LnGDPC }+\beta_{2} \text { LnCBEC }+\varepsilon_{t}
$$

The data used in this paper cover the time period of 2005-2020. GDPC and OPEN are taken from the World Development Indicators. CBEC data taken from Ali Research Institute and China E-commerce Research Center.

\subsection{Methodology}

Following Bakari (2019), this study uses the Autoregressive Distributed Lag (ARDL) approach to co-integration to check the long-run relationship among the variables. The model can be specified as follows:

$$
\begin{gathered}
\Delta \text { LnOPEN }_{\mathrm{t}}=\beta_{0}+\delta_{1} \mathrm{LnOPEN}_{t-1}+\delta_{2} \mathrm{LnGDPC}_{t-1}+\delta_{3} \mathrm{LnCBEC}_{t-1}+\sum_{i=0}^{p} \alpha_{i} \Delta \operatorname{LnOPEN}_{t-i}+ \\
\sum_{i}^{q} \varphi_{i} \Delta \mathrm{LnGDPC}_{t-i}+\sum_{i}^{q} \gamma_{i} \Delta \operatorname{LnCBEC}_{t-i}+\varepsilon_{t}
\end{gathered}
$$

Where $\Delta$ : difference operator; $\delta_{i}$ : lon g-run multipliers; $\beta_{0}$ : intercept; $\varepsilon_{t}$ : error terms, $\mathrm{p}$ and q: appropriate ARDL model orders. The first part of the equation with $\delta_{1}, \delta_{2}$, and $\delta_{3}$ represent the long-run relationship and parameters $\alpha_{i}, \varphi_{i}$, and $\gamma_{i}$ the short-run dynamic of the model.

The null hypothesis of the model is:

$\mathrm{H}_{0}: \delta_{1}=\delta_{2}=\delta_{3}$ (there is no long-run relationship)

Against the alternative

$\mathrm{H}_{A}: \delta_{1} \neq \delta_{2} \neq \delta_{3}$

The first step of the ARDL procedure is to perform the bound test in order to check the existence of a long-run relationship among the variables. The calculated F-statistic is compared with the critical value estimated by Pesaran et al. (2001). The upper bound of the F-test indicates that all the variables are I(1), and the lower bound of the F-test suggests that all the variables are $\mathrm{I}(0)$. If the value of F-statistic appears above the upper bound, we rejected $\mathrm{H}_{0}$. If the value F-statistic falls below the lower critical bound, we cannot rejected $\mathrm{H}_{0}$. If the value of F-statistic is within the upper and lower bounds, this implies that the test is inconclusive. 
If there is co-integration among variables, the ARDL model for the long-run equation can be:

$$
\Delta \text { LnOPEN }_{\mathrm{t}}=\alpha_{0} \sum_{i=0}^{q} \delta_{1} \operatorname{LnGDPC}_{t-i}+\sum_{i=0}^{q} \delta_{2} \operatorname{LnCBEC}_{t-i}+\varepsilon_{t}
$$

To capture the short term dynamics, the Error Correction Model (ECM) will be:

$$
\Delta \text { LnOPEN }_{\mathrm{t}}=\beta_{0}+\sum_{i=0}^{q} \varphi_{1} \Delta L n G D P C_{t-i}+\sum_{i=0}^{q} \Delta \operatorname{LnCBEC}_{t-i}+\varepsilon_{t}
$$

$\varphi_{1}$ and $\varphi_{2}$ are the short term dynamic coefficients convergent to equilibrium, whereas is the speed of adjustment to long-run equilibrium following a shock to the system.

We will conduct diagnostic and stability tests to check the robustness of the model. Serial correlation and heteroscedasticity and Jarque- bera tests will be used for diagnostic tests. Both Cumulative Sum (CUSUM) and Cumulative Sum Squares (CUSUMSQ) are used to test the stability of estimated coefficients.

\section{Empirical Results and Discussion}

\subsection{Stationarity Tests}

Before performing the ARDL co-integration test, the unit root test is used to check the stationarity of all the variables. Thus, we will use ADF and PP unit root tests in this paper. Table 1 shows that except for cross-border e-commerce(CBEC), which is stationary at level or integrated at $\mathrm{I}(0)$, all other variables are stationary at the first difference or integrated at I(1). Therefore, the conditions required to conduct the ARDL co-integration test are satisfied.

Table 1. Result of unit root tests

\begin{tabular}{lcccc}
\hline & \multicolumn{2}{c}{ ADF Test } & \multicolumn{2}{c}{ PP Test } \\
\cline { 2 - 5 } Variables & At level & At First Difference & At level & At First Difference \\
\hline lnOPEN & -0.988 & $-3.581^{* *}$ & -0.776 & $-6.733^{* * *}$ \\
lnGDPC & -1.044 & $-3.643^{*}$ & -1.432 & $-4.131^{* *}$ \\
$\operatorname{lnCBEC}$ & $-4.575^{* * *}$ & $-6.265^{* * *}$ & $-5.428^{* * *}$ & $-13.538^{* * *}$ \\
\hline
\end{tabular}

Note. $* * * * *$ and $*$ mean stationary of variables at $10 \%, 5 \%$ and $1 \%$ level of significance.

\subsection{ARDL Bounds Test for Co-Integration}

In order to ensure the existence of a long-run co-integrating relationship between the variables of our models, we perform the Bound Test. The results of the bounds test for ARDL are presented in Table 2.

\begin{tabular}{|c|c|c|c|c|}
\hline Models & Functions & F-statistic & \multicolumn{2}{|c|}{ Co-integration Status } \\
\hline 1 & $\mathrm{~F}(\mathrm{LnOPEN} / \mathrm{LnGDPC}, \mathrm{LnCBEC})$ & $63.617 * * *$ & \multicolumn{2}{|c|}{ Co-integrated } \\
\hline 2 & F(LnGDP/LnOPEN, LnCBEC) & $112.873 * * *$ & \multicolumn{2}{|c|}{ Co-integrated } \\
\hline \multicolumn{5}{|c|}{ Critical Value Bounds } \\
\hline $1 \%$ & $5 \%$ & & $10 \%$ & \\
\hline $\mathrm{I}(0)$ & $\mathrm{I}(0)$ & $\mathrm{I}(1)$ & $\mathrm{I}(0)$ & $\mathrm{I}(1)$ \\
\hline 5.15 & 6.36 & 4.85 & 3.17 & 4.14 \\
\hline
\end{tabular}

Table 2. Results of ARDL Bounds test to Co-integration

Note. *** means significant at $1 \%$ level.

From Table 2, we see that F-statistic values (about 63.62 and 112.87) are greater than the critical value at a $1 \%$ level of significance. This implies that the null of the long-run relationship is not accepted. Therefore, there exists a long-run co-integration between the variables.

\begin{tabular}{|c|c|c|c|c|}
\hline \multicolumn{5}{|c|}{ Long-Run Coefficients } \\
\hline Models & \multicolumn{2}{|c|}{ Model 1(LnOPEN) } & \multicolumn{2}{|c|}{ Model 2(LnGDPC) } \\
\hline Variables & Coefficient & T-statistic & Coefficient & T-statistic \\
\hline LnGDPC & $0.305^{* *}$ & 5.407 & & \\
\hline LnOPEN & & & 0.220 & 0.391 \\
\hline LnCBEC & $0.269 * *$ & 4.377 & $0.590^{* *}$ & 3.457 \\
\hline
\end{tabular}

Table 3. Results of long-run and short-run estimates 


\begin{tabular}{|c|c|c|c|c|}
\hline \multicolumn{5}{|c|}{ Short-Run Coefficients } \\
\hline DLnGDPC & $2.170 * * *$ & 23.005 & & \\
\hline DLnGDPC(-1) & $0.727 * * *$ & 8.259 & & \\
\hline DLnOPEN & & & $0.595^{* * *}$ & 8.741 \\
\hline DLnOPEN(-1) & & & $0.235^{* * *}$ & 6.081 \\
\hline DLnCBEC & $0.081 * * *$ & 8.762 & $0.014 * *$ & 3.856 \\
\hline DLnCBEC(-1) & $-1.186^{* * *}$ & -18.072 & -0.006 & -0.469 \\
\hline $\mathrm{C}$ & $-0.185^{* * *}$ & -19.748 & $1.060 * * *$ & 23.283 \\
\hline ECM & $-0.696^{* * * *}$ & -20.861 & $-0.158 * * *$ & -20.865 \\
\hline $\mathrm{R}^{2}$ & 0.997 & & 0.985 & \\
\hline Adjusted $\mathrm{R}^{2}$ & 0.994 & & 0.978 & \\
\hline F-Statistics(Prob) & $350.222(0.000)$ & & $147.417(C$ & \\
\hline DW-Statistic & 2.552 & & 3.101 & \\
\hline
\end{tabular}

\subsection{Discussions of the Results}

\subsubsection{Discussions on the Effect of Cross-Border E-Commerce (CBEC) on China's International Trade}

- The impact of CBEC on international trade is positive and significant in both the short and long run. Specifically, an 1 percent increase in cross-border e-commerce will raise China's international trade by 0.08 percent and 0.26 percent, respectively, in the short and long- run. The results are consistent with the theory of Terzi, who states that cross-border e-commerce tends to reduce trade barriers and promote trade growth. It is also in line with the empirical outcome of Wang et al. (2017) and Zhu (2017). However, in the short-run at lag one, cross-border e-commerce decrease trade in China. This confirms the empirical finding of Yao (2019).

- The impact of economic growth on international trade is also positive and significant in both the long -run and the short -run. This means that increasing economic growth by 1 percent will increase China's international trade by 0.30 percent and 2.17 percent, respectively, in the long and short run. The result is consistent with $\mathrm{Li}$ et al. (2010), who demonstrated a positive and significant link between them.

-The coefficient of ECM is statistically significant with a negative sign, which confirms the existence of a long-term relationship between variables.

-The coefficient of the $\mathrm{R}^{2}$ value is 0.99 , which implies that the independent variables jointly account for about 99 percent of the variation in international trade. Subsequently, the remaining 1 percent may be due to other factors. The value of the F-statistic value (350.22) is statistically significant (probability: 0.000 ). Our model is globally well specified. The value of the Durbin- Watson statistic (2.55) indicates the absence of auto-correlation in the estimated model.

\subsubsection{Discussions on the Effect of Cross-Border E-Commerce on China's Economic Growth}

- The impact of CBEC on economic growth is positive and significant in both the long-run and short-run. Specifically, this implies that a 1 percent increase in cross-border e-commerce will raise China's economic growth by 0.59 percent and 0.014 percent, respectively, in the long-run and short run. The result is in line with the expected sign and the theory, which stated that cross-border e-commerce by reducing transaction cost improve the efficiency of foreign trade and thus promotes domestic economic growth. It is also in line with the empirical findings of Yu. (2017) and Ma et al. (2020).

- The coefficient of international trade is positive in both the long-run and short-run. This result is consistent with the expected sign and the findings of several authors ( such as Hye et al., 2016; Khalid \& Ali, 2017; and Kong et al., 2021). However, the long-run result is contrary to the findings of Majumder and Rahman (2020), who found a negative linkage between trade and GDP in the long run in China.

- The coefficient of ECM is statistically significant with a negative sign, which confirms the existence of a long-term relationship between variables.

- The coefficient of the R-squared value is 0.98 , which implies that the independent variables jointly account for about 98 percent of the variation in economic growth. Subsequently, the remaining 2 percent may be due to other factors. The value of F-statistic (147.42) is statistically significant at a 1 percent level of significance (probability:0.000). Our model is globally well specified. The value of Durbin- Watson (3.10) indicates the absence of auto-correlation in the estimated model. 


\subsection{ARDL Model Robustness Tests}

\subsubsection{Diagonostic Tests}

The validation of our estimated models and the results obtained require some diagnostic tests, namely serial correlation, heteroskedasticity, and normality. Indeed, the results below show that the probability of the statistic for each test is greater than 5\%. Therefore we accept the null hypothesis, which supposes that the errors are not autocorrelated, are homoscedastic, and normally distributed.

Table 4. Results of Diagonostic Tests

\begin{tabular}{lcccc}
\hline & \multicolumn{2}{c}{ Model 1 } & \multicolumn{2}{c}{ Model 2 } \\
\cline { 2 - 4 } Diagnostic Tests & Test Statistic & Prob-Value & Test Statistic & Prob-Value \\
\hline Serial Correlation & 0.534 & 0.695 & 5.123 & 0.062 \\
Heteroskedasticity & 1.154 & 0.498 & 1.495 & 0.304 \\
Normality & 0.31 & 0.855 & 0.086 & 0.958 \\
\hline
\end{tabular}

\subsubsection{Stability Test}

Finally, Figures 1 and 2 below present successively the stability test results of models 1 and 2 . From all the figures, we can see that the plots of CUSUM are within the 5\% significance level interval, which allows us to say that the estimated coefficients of the models in the short and long term are characterized by structural stability.
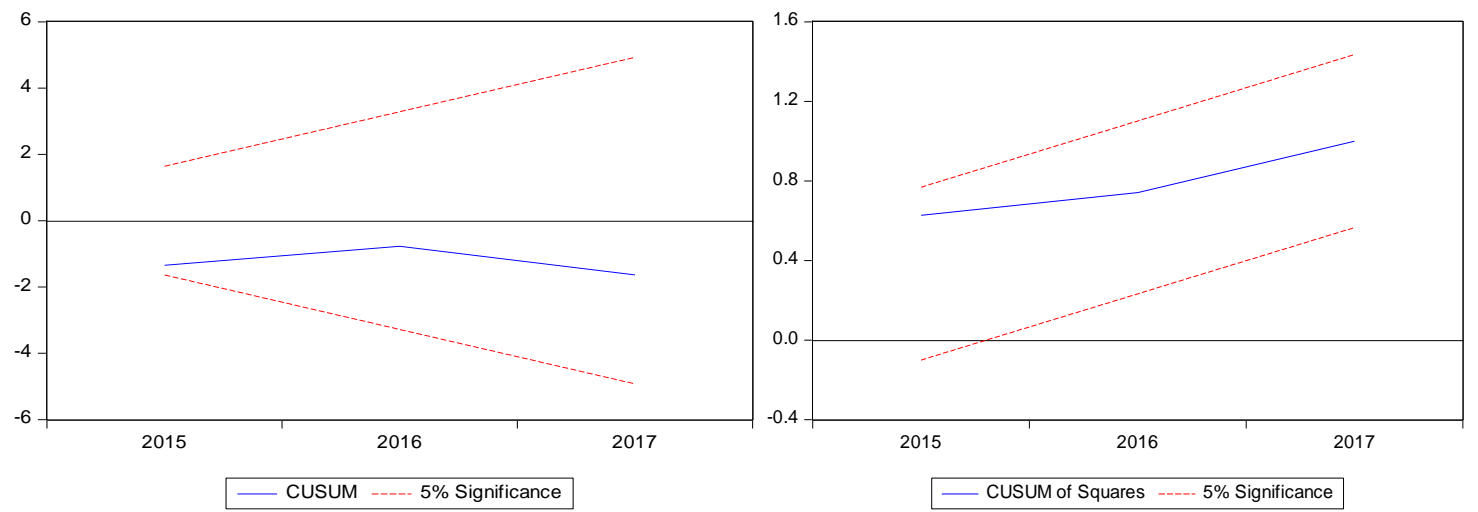

Figure 1. CUSUM and CUSUMQ tests for model 1
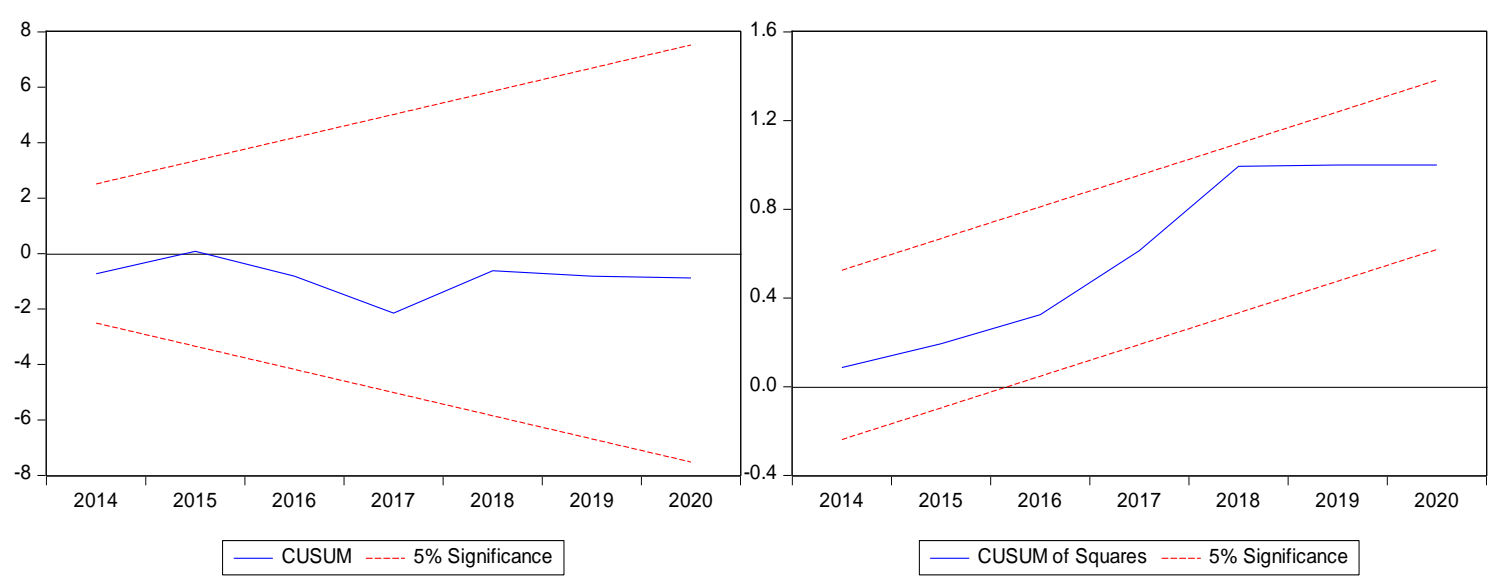

Figure 2. CUSUM and CUSUMQ tests for model 2 


\section{Conclusion and Recommendations}

This paper aimed to examine the impact of cross-border electronic commerce on China's international trade and economic growth from 2005 to 2020. For this, we used an econometric model ARDL to test the relationship between them. The results revealed that cross-border e-commerce positively and significantly influences international trade and economic growth in the short and long term. Also, we found a positive relationship between economic growth and international trade during the period under study. Therefore, the government should further support the development of cross-border e-commerce through customs clearance process optimization, payment agencies supervision, pilot port expansion, and free trade zone establishment. Since SMEs employ over 80 percent of urban jobs and contribute to over $65 \%$ of China's GDP, the government must encourage them to engage in CBEC. In addition, the government could use the Belt and Road infrastructure to cultivate e-commerce partnerships with the countries along the Belt and Road. However, the lack of cross-border e-commerce data for some years is the limitation of this paper. Further research with more and better data would be needed to reexamine the relationship between them. Moreover, some factors such as financial crisis, fiscal policy, or transportation cost must be incorporated into future research.

\section{References}

He, Y., \& Wanf, J. (2019). A Panel Analysis on the Cross Border E-commerce Trade: Evidence from ASEAN Countries. Korea Distribution Science Association. https://doi.org/10.13106/jafeb.2019.vol6.no2.95

Li, T. (2017). A Tentative Study on the Advantages of Cross-Border E-Commerce Development in Chongqing China. Advances in Social Science, Education and Humanities Research, 179.

$\mathrm{Li}$, W. (2020). The Impact of Cross-Border e-Commerce Development on China's International Trade and Economic Development. International Journal of New Developments in Education, 2(6) 4-7. https://doi.org/10.25236/IJNDE.2020.020602

Ma, S., Lin, Y., \& Pan, G. (2021). Does Cross-Border E-Commerce Contribute to the Growth Convergence?An Analysis Based on Chinese Provincial Panel Data. Journal of Global Information Management (JGIM), 29(5). https://doi.org/10.4018/JGIM.20210901.oa6

Qin, Y., \& Bryna, M. (2018). Effect of Cross-border E-commerce on International Trade of emerging countries in the case of China. Malaysian E Commerce Journal, 2(1), 11-14. https://doi.org/10.26480/mecj.01.2018.11.14

Wang, C. (2021). Analyzing the Effects of Cross-Border E-Commerce Industry Transfer Using Big Data. Hindawi Mobile Information Systems, 221, 12. https://doi.org/10.1155/2021/9916304

Wang, C., Liu, T., \& Duo, W. (2021). The Impact of International Electronic Commerce on Export Trade: Evidence from China. Journal of Theoretical and Applied Electronic Commerce Research, 16(7), 2579-2593. https://doi.org/10.3390/jtaer16070142

Xingzhi, L., \& Rongkun, L. (2017). The Comparison and Analysis of China Cross-border E-commerce Business Model. Advances in Intelligent Systems Research (AISR), 142. https://doi.org/10.2991/itim-17.2017.22

Yao, L., \& Yan, Z. (2019). An Empirical Study of Cross-border E-commerce's Influence on Traditional Import and Export Trade. Advances in Social Science, Education and Humanities Research (ASSEHR), 314.

Yichen, L. (2021). Analysis on the Cross-Border E-Commerce Under COVID-19. Advances in Social Science, Education and Humanities Research, 543. https://doi.org/10.2991/assehr.k.210407.030

Yuan, W., Jing, W., \& Yihua, Z. (2020). Study on the Influence Mechanism of Cross-border E-commerce and Foreign Trade Import and Export 2020. International Conference on Big Data Application \& Economic Management.

Yuan, Y. L. (2020). Empirical Analysis of the Impact of China's Cross-border Electronic Commerce on Foreign Trade Based on VAR Model. Journal of Physics: Conference Series. https://doi.org/10.1088/1742-6596/1533/2/022064

Yurtkur, A. K. (2020). An Empirical Study on the Relationship Between Economic Growth and E-Commerce. IGI Global Scholarly Journals. https://doi.org/10.4018/978-1-7998-0035-4.ch004

Zhang, K., Yan, Z.,Wan, Q., Li, S., \& Yao, L. (2018). The Impact of Cross-border E-commerce on Traditional Import and Export Trade in China. 2018 International Conference on E-commerce and Contemporary Economic Development (ECED 2018). https://doi.org/10.12783/dtem/eced2018/23930

Zhang, Y. (2018). A Brief Analysis on Effect of Cross-border E-commerce for Small and Medium-sized Trade 
Enterprises Development in China. 2018 4th International Conference on Social Science and Management (ICSSM 2018). https://doi.org/10.12783/dtssehs/icssm2018/27068

Zheng, Y., \& Zhang, C. (2020). The Impact of Cross-border E-commerce on China's Agricultural Products Export: -An Empirical Study Based on Big Data Processing. International Conference on Big Data and Social Sciences (ICBDSS). https://doi.org/10.1109/ICBDSS51270.2020.00032

\section{Copyrights}

Copyright for this article is retained by the author(s), with first publication rights granted to the journal.

This is an open-access article distributed under the terms and conditions of the Creative Commons Attribution license (http://creativecommons.org/licenses/by/4.0/). 